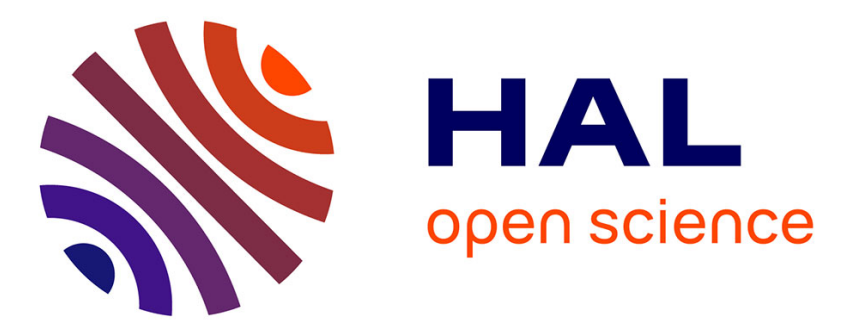

\title{
Demystifying Fair Trade in France: The History of an Ambiguous Project
}

Nil Özçağlar-Toulouse, Amina Béji-Bécheur, Matthieu Gateau, Philippe

Robert-Demontrond

\section{- To cite this version:}

Nil Özçă̆lar-Toulouse, Amina Béji-Bécheur, Matthieu Gateau, Philippe Robert-Demontrond. Demystifying Fair Trade in France: The History of an Ambiguous Project. Journal of Business Ethics, 2010, 92 (S2), pp.205-216. 10.1007/s10551-010-0579-x . hal-01598067

\section{HAL Id: hal-01598067 \\ https://u-bourgogne.hal.science/hal-01598067}

Submitted on 5 Oct 2017

HAL is a multi-disciplinary open access archive for the deposit and dissemination of scientific research documents, whether they are published or not. The documents may come from teaching and research institutions in France or abroad, or from public or private research centers.
L'archive ouverte pluridisciplinaire HAL, est destinée au dépôt et à la diffusion de documents scientifiques de niveau recherche, publiés ou non, émanant des établissements d'enseignement et de recherche français ou étrangers, des laboratoires publics ou privés. 


\section{Demystifying Fair Trade in France: The History of an Ambiguous Project}

\author{
Nil Özçă̆lar-Toulouse \\ Amina Béji-Bécheur \\ Matthieu Gateau \\ Philippe Robert-Demontrond
}

ABSTRACT. In France, Fair Trade arrived on the scene in the late twentieth century, and since then has passed through several experimental phases before becoming an enduring "realistic" economic alternative. To understand the transformation, this article defines Fair Trade as a social construct issues and tensions of which change depending on the point of entry. By conducting a secondary analysis of several data sets from varied sources, including documentary material, interviews, and observations, the authors trace the history of Fair Trade in France, define its introduction as a system, describe its institutionalization, and contribute to a greater understanding of how its ideals have changed and become more professional over time. The analyses reveal that the term "Fair Trade" has become ambiguous, spanning divergent and conflicting ideas and projects, including opening and

Dr. Özçağlar-Toulouse is the lead author of this article. The other authors' names are listed alphabetically: each contributed equally to this article.

Nil Özçăglar-Toulouse is an Assistant Professor of Marketing at the University of Lille Nord de France and an affiliated researcher at the Lille School of Management Research Center. She is the President of FairNESS, a research network on Fair Trade (www. fairness. fr).

Amina Béji-Bécheur is an Assistant Professor of Marketing at the Université Paris-Est (France) and an affiliated researcher at the Management Research Center (IRG). She is a member of the FairNESS network.

Matthieu Gateau is an Assistant Professor of Sociology at the Université de Bourgogne in Dijon (France) and an affiliated researcher at the Centre Georges Chevrier (UMR CNRS 5605). He is a member of the FairNESS network.

Philippe Robert-Demontrond is a Professor of Marketing at the University of Rennes 1 (France) and the director of a research group at the CREM (Centre de Recherches en Economie et management), UMR CNRS. closing conventional market systems and alter-globalization and anti-globalization.

KEY WORDS: alter-/anti-globalization Fair Trade, France, history, institutionalization, networks, professionalism

For more than 40 years, Fair Trade has evolved in France as a series of concrete experiences, initially limited in coverage but eventually extending to a broad scope. Certainly, Fair Trade is not yet fully institutionalized and has further room to grow; yet, it has moved beyond experimental phases and has now become an enduring part of the landscape. This development implies that the architects of Fair Trade constructed a network, over time, for organizing commercial exchanges that gradually has won support from public opinion, as well as from political and economic actors (Bécheur and Toulouse, 2008).

The nature of French Fair Trade has changed in parallel with the increasing number of participants from the industrial organizations and the greater accessibility of the concept. For example, the number of organizations (e.g., international solidarity associations, importers, boutiques etc.) and production networks continue to increase, and sales of products from channels labeled as specializing in Fair Trade have expanded.

Specifically, Fair Trade turnover in France increased by a factor of almost nine between 2000 and 2005 - from 17 million Euros to more than 150 million (Krier, 2005). According to its Web site, ${ }^{1}$ Artisans du Monde multiplied its turnover by 2.5-fold between 2000 and 2006, and its points of sale increased from 97 to 168 . The Max Havelaar 


\section{Nil Özçağlar-Toulouse et al.}

France Association, which distributes its labeled products in more than 45,000 points of sale (e.g., supermarkets, hypermarkets, hotels, boutiques etc.) enhanced the value of its branded products by a factor of almost 30 between 2000 and 2006 - from 5.6 million to 166 million Euros. Other major Fair Trade names, including Minga or Ethiquable, enjoyed impressive turnovers of 7 million Euros in 2005 and 17 million Euros in 2007, respectively. This boom in Fair Trade - which coincided with greater public recognition, from $9 \%$ in 2000 to $81 \%$ in 2007 (IPSOS/Max Havelaar, 2007) - resulted partially from improved retail distribution capabilities (Gateau, 2008).

Similar increases mark the number and frequency of events dedicated to Fair Trade (e.g., International Solidarity Week and Fair Trade Fortnight since 2000; National Fair Trade Forum since 2005; and European Conference on Fair Trade Towns in 2009) and the interest shown in it among nonspecialized media. Furthermore, researchers from various disciplines, including sociology, anthropology, economics, and agronomy, now pay more attention to Fair Trade. Encouraged by this interest, French Fair Trade associations attempt to close the gap that they sense with their European counterparts ${ }^{2}$ by actively promoting Fair Trade on a larger commercial scale.

To understand these developments, we examine the actors responsible for the Fair Trade market in France. Thus, we attempt to move beyond initial efforts to map Fair Trade, which focused on describing the functional, bipolar opposition of two types of operational relationships designed to market Fair Trade through retail distribution: constructing integrated channels or devising branding systems for commercial offers. We define Fair Trade, similar to other authors (Béji-Bécheur et al., 2008), as a social construct that depends on the level of analysis, with sometimes porous borders between categories, which at the same time explains our analysis of their values (macro level) and of their practices (micro level).

Our unique approach to Fair Trade makes systematic use of different scales of observation and thus various points of view (Desjeux, 2004) to study a market that is in a constant state of development and that interacts with the institutional culture. We consider Fair Trade-related values and practices, depending of the level of analysis. In addition, we offer an updated and diverse portrait of Fair Trade in France, based on some of its main actors, and help provide a broader understanding of recent evolutions that have shaped the Fair Trade sector.

\section{Method}

We conducted a secondary analysis of several data sets over 3 years (2004-2007). These data sets include information about the French Fair Trade industry that markets products in various retail outlets, importers, distributors, nongovernmental organization (NGO) members, and public representatives.

The data sets feature qualitative data, obtained in three ways: First, we conducted a critical historical analysis of documents produced by Fair Trade actors that were addressed to the general public, internal and external documents of NGOs, and publications by conventional companies, as well as scientific and journalistic articles. Second, we attended various events, including information meetings and stakeholders' sessions that were open to the public, Artisans du Monde open access days, industry fairs, discussion forums, and debates. Third, we complemented our observations with 152 focused, recorded, and transcribed, semi-structured interviews with Fair Trade organizations (whether activists or employees) and representatives of the public (see Table I). The interviews were carried out in Paris and surrounding areas, Brittany (Rennes), and Burgundy (Dijon). They were previously collected by the authors together or individually. This extensive material provides the basis for the case studies that we use throughout this article.

Because the full qualitative data sets are available and they were contextualized and interpreted by the authors together, a secondary analysis of the data is possible. Our in-depth analysis adopts an iterative approach designed to establish a research area rather than a research question. From a sociological perspective, this comprehensive approach seeks to ensure the subjectivity of the actors and reveal their critical decision-making process, including their discursive and collective appropriation of the strategic projects undertaken by their organizations (Weber, 1971). It also enabled us to evaluate the history of Fair Trade in France, because that history 
Demystifying Fair Trade in France

TABLE I

Sampling

\begin{tabular}{llllr}
\hline Type of organization & \multicolumn{1}{c}{ Level } & City & \multicolumn{1}{c}{ Type of interviewee } & Number \\
\hline NGO & Local/regional & Dijon & Activist & 30 \\
NGO & Local & Dijon & Employee & 10 \\
NGO & National & Paris & Employee & 4 \\
NGO & National & Paris & Activist & 6 \\
NGO & Local/regional & Paris & Activist & 10 \\
Company & National & Paris & Brand founder, employee, retailer & 31 \\
NGO & Local/regional & Rennes & Activist & 35 \\
NGO & Local & Rennes & Founder or executive director & 11 \\
NGO & Local & Rennes & Employee & 15 \\
\hline
\end{tabular}

was created by the actors in the industry and the characteristics of the industry itself.

The subsequent contextual analysis of the data employs a neoinstitutionalist approach (Hasselbladh and Kallinikos, 2000; Moquet and Pezet, 2006) and considers various levels, such as the macro (e.g., national publications, documents from national-level NGOs and companies), meso (e.g., publications by local NGOs, regional organizations, and private initiatives), and micro (the management techniques of organizations) levels.

\section{Evolution of Fair Trade in France}

According to the interviews, three major periods mark the evolution of the ideals of Fair Trade in France, as we show in Figure 1. The first period corresponds to the emergence of Fair Trade between 1974 and 1980, when actors operating outside conventional trade markets initiated a novel approach to exchanges. Between 1981 and 1999, the participants organized and developed national and international structures that represented Fair Trade institutions. Finally, in the third stage, from 2000 to 2007 and likely continuing until now, the change in scale in Fair Trade called into question its original definition and provoked new networks of actors and new interested parties. These three periods, synthesized according to the macro, meso, and micro levels, enable us to determine precisely how the Fair Trade market in France has developed.
Based on Hasselbladh and Kallinikos' (2000) neoinstitutionalist approach, we posit that the macro level relates to ideals and views of why Fair Trade exists and its definition. The meso level pertains to its object status and defines the field of action. Finally, the micro level, which features a subjective assessment, highlights social roles and management techniques adopted by Fair Trade actors.

Macro level: solidarity, fairness, and normalization of ideals

The analysis of macro-level ideals reveals the values of the Fair Trade operators. The emergence of Fair Trade in France emphasized the humanistic values of pioneer NGOs, such as Artisans du Monde. Its transformation to adopt more commercial profitoriented values coincided with the entry of Fair Trade into the mainstream.

\section{Emergence of the Fair Trade ideal}

The years marking the emergence of Fair Trade (1974-1980) corresponds to a period during which actors from conventional trade markets initiated a new approach to exchanges. In light of increasing awareness of food shortages and hunger in other countries, some actors mobilized to find a solution and thus developed relationships. Fair Trade began in France when the renowned priest Abbé Pierre took action to come to the aid of Bangladesh (which suffered from civil war and severe floods) and 


\begin{tabular}{|c|c|c|c|c|}
\hline & 1974-1980 & 1981-1999 & \multicolumn{2}{|c|}{ Since 2000} \\
\hline & $\sqrt{n}$ & 苘 & $\sqrt{n}$ & $\sqrt{n}$ \\
\hline \multirow[t]{2}{*}{ 急 } & $\begin{array}{l}\text { Solidarity with } \\
\text { impoverished people } \\
\text { Development }\end{array}$ & $\begin{array}{l}\text { Equality between countries } \\
\text { Sustainable development } \\
\text { Corporate responsibility/ethics }\end{array}$ & $\begin{array}{l}\text { Social justice/morality in business } \\
\text { Corporate social responsibility } \\
\text { Alter-globalization } \\
\text { Pragmatism } \\
\text { Dominating nature }\end{array}$ & $\begin{array}{l}\text { Negative growth } \\
\text { Voluntary simplicity } \\
\text { Anti-globalization } \\
\text { Local development } \\
\text { Being one with nature }\end{array}$ \\
\hline & $\sqrt{n}$ & $\sqrt{n}$ & $\sqrt{n}$ & $\sqrt{n}$ \\
\hline \multirow[t]{2}{*}{$\sum_{1}^{\infty}$} & $\begin{array}{l}\text { "Fair Trade not aid" } \\
\text { "Alternative trade" }\end{array}$ & $\begin{array}{l}\text { "Fair Trade must develop" } \\
\text { Alter-globalization } \\
\text { Respect for the environment } \\
\text { International organization of Fair Trade }\end{array}$ & $\begin{array}{l}\text { Global governance } \\
\text { Economic regulation } \\
\text { Global Fair Trade organization } \\
\text { Subsidies-source of inequalities } \\
\text { "The concept of Fair Trade goes } \\
\text { further morally than simple trade } \\
\text { relations" } \\
\text { "Economic performance is } \\
\text { supported by private } \\
\text { entrepreneurs" }\end{array}$ & $\begin{array}{l}\text { Alternative economy } \\
\text { "The market is not perfect" } \\
\text { "Conventional actors are } \\
\text { opportunists and cannot support } \\
\text { the public interest" } \\
\text { "The State must intervene" } \\
\text { "Globalization is risky" }\end{array}$ \\
\hline & $\sqrt{n}$ & $\sqrt{n}$ & $\sqrt{n}$ & $\sqrt{n}$ \\
\hline \multirow[t]{2}{*}{ 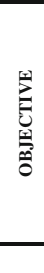 } & $\begin{array}{l}\text { Support organizations of } \\
\text { disadvantaged producers }\end{array}$ & $\begin{array}{l}\text { Organized Fair Trade channels (Fair Trade labels) } \\
\text { Sale through retail distribution } \\
\text { International networks } \\
\text { Ethical scoring }\end{array}$ & $\begin{array}{l}\text { Public contracts code } \\
\text { Publication of an information } \\
\text { manual } \\
\text { International trade } \\
\text { Development of Fair Trade } \\
\text { management } \\
\text { Fair Trade brands created by } \\
\text { companies, NGO-company } \\
\text { alliances, global NGOs }\end{array}$ & $\begin{array}{l}\text { Local Fair Trade } \\
\text { AMAPs } \\
\text { Regional Fair Trade network } \\
\text { Fair Trade in organic products }\end{array}$ \\
\hline & $\sqrt{n}$ & $\sqrt{n}$ & n & $\sqrt{n}$ \\
\hline$\sum_{\substack{1\\
}}^{\infty}$ & $\begin{array}{l}\text { "The appeal of the } \\
\text { communes of France" } \\
\text { Entrepreneurial and } \\
\text { whistle blowing role of } \\
\text { NGOs }\end{array}$ & $\begin{array}{l}\text { NGOs: Essential actors in civil society and interested } \\
\text { parties, whether in partnership with or critical of } \\
\text { companies and the State } \\
\text { "The State must become responsible once again" } \\
\text { "Companies must be ethical and responsible" } \\
\text { Consumers use conscience and their power to act }\end{array}$ & $\begin{array}{l}\text { Companies driving the economy } \\
\text { must be responsible } \\
\text { NGOs lobby and help companies } \\
\text { to improve } \\
\text { Consumers take on roles as actors } \\
\text { Ethical fashion, banks }\end{array}$ & $\begin{array}{l}\text { Producers must organize their } \\
\text { own future. } \\
\text { Fair Trade is not a market niche. } \\
\text { Consumers are citizens. }\end{array}$ \\
\hline
\end{tabular}

Figure 1. The evolution of Fair Trade in France.

launched an "appeal to the communes of France." Following his appeal, dozens of committees emerged through cooperative acts among communities. In the wake of these actions, the first Artisans du Monde $^{3}$ boutique opened in Paris in 1974. Its objective was to redress the balance in trade relations by paying a fair price to producers in less developed countries. Then from 1981 to 1999, the actors organized and structured their actions in accordance with international and national organizations. Fair Trade thus during this period was perceived as related to commercial exchanges, sustainable development, and corporate social responsibility.

\section{Defining Fair Trade}

During the third phase (since 2000), actors have begun to question the existing definition of Fair Trade in response to the emergence of new networks, new stakeholders, and new ideals, such as the developing "mainstream Fair Trade." After exhibiting mostly indifference for many years, the French government decided to support Fair Trade by initially engaging in Fair Trade in its public purchases, which now constitute almost one-third of the sales of Fair Trade products in France (Diaz Pedregal and Ozcaglar-Toulouse, 2009). Since 2004, the Public Contracts Code has permitted the consideration of environmental and social issues in the public purchasing process. Thus, the Presidential palace, Parliament, and certain town halls consume some Fair Trade products, and the government, which is responsible for public well-being and the interests of the country, is progressively becoming an "activist administration" (Spanou, 1991).

In 1999, the idea of finding a common denominator to define the actions of all Fair Trade actors spurred the French government to provide a legal framework. A collection of Fair Trade organizations participated in the discussion and creation of a working group within the French Normalisation Association (Afnor), with the objective of arriving at an experimental norm. This initiative sparked some attempts at reappropriation by the more activist community; France was keen to position itself as among the most advanced countries in terms of promoting Fair Trade. However, the French project failed in 2005 as a result of dissension among representatives of the retail industry and associations 


\section{Demystifying Fair Trade in France}

from the Fair Trade industry. This failure highlights the divergence in visions of Fair Trade in France. The first view, held by long-time actors who wish to maintain the principal ideals of the Fair Trade founders and militants, argues that "The fact that these companies [the retail industry] are committing to the cause is a good thing. The bad thing is that they are describing what they do as Fair Trade. The concept of Fair Trade goes further morally than simple trade relations that consist merely of paying a good price - it involves a much more all-encompassing approach" (V. Ferreira, former chairperson, Max Havelaar-France). The second view, as maintained by representatives of the State and professional organizations, proposes regulating and controlling Fair Trade sectors as part of a process to institutionalize Fair Trade.

The problem thus lies in the clash between the typical ideals embraced by these two categories of actors. Due to these extreme differences, the aim of constructing a Fair Trade norm was temporarily replaced with the objective of publishing a simple information manual. This manual, published in March 2005, defines the generic criteria for Fair Trade initiatives but does not have the binding power that the norm was intended to provide. This attempt at normalization therefore constitutes "a first step toward recognizing Fair Trade via the legislative route" (Herth, 2005, p. 78). In the same vein, the State showed renewed interest in Fair Trade when it commissioned French MP Antoine Herth (2005) to draw up an institutional report on Fair Trade. The report also represented an initiative to "translate" existing texts and views relating to Fair Trade into an official, legitimate, institutionalized document (Diaz Pedregal and Ozcaglar-Toulouse, 2009).

Finally, in August 2005, a new law passed that contained an article pertaining to Fair Trade. ${ }^{4}$ The article stipulates that Fair Trade is part of any strategy for sustainable development and that it "organizes exchanges of goods and services between developed countries and disadvantaged producers located in developing countries." According to French law then, Fair Trade is reserved strictly for trade exchanges between more and less developed countries, an approach disputed for its exclusively Third World focus. The provision implementing this legislative article also stipulates the implementation of a National Fair Trade Commission (CNCE), to be "charged with granting recognition to persons who monitor that the terms and conditions set out under Article 60 of the abovementioned Law of 2 August 2005 are observed by bodies seeking to participate in exchanges of goods and services falling within the scope of Fair Trade" (Decree 2007-986). That is, the Fair Trade label applies not so much to products as to bodies that engage in a Fair Trade approach. This wording emphasizes the importance of the historical actors (e.g., Artisans du Monde, Max Havelaar) that would prefer that fair exchanges remain their exclusive provenance, instead of that of private enterprises.

Because of the vast number of ideals associated with Fair Trade practices, a legitimate or official form of Fair Trade does not yet exist. The definitions previously established for relevant Fair Trade measures continue to be challenged, and in this context, the actors define the rules as they go, constantly negotiating for changes in the definition of Fair Trade.

Meso level: national organization

in networks that develop over time

To gain a better understanding of the market structure for Fair Trade in France, we address Fair Trade from a social relationships perspective to examine how the actors define their field of action and how they implement networking.

\section{Transformation of the systems}

During 1974-1980, Fair Trade developed through associative milieu. Specifically, the Fair Trade channels diversified in terms of the structure of the groups of producers in underdeveloped countries and the nature of the distribution channels in France. Discussions focused on the structure of the movement to guarantee its visibility and coherence at the international level. Thus, during 1981-1999, a modern structure of networks emerged that benefitted the actors involved. Other associations, such as ASPAL, Artisanat SEL, and Artisans du Soleil, also established Fair Trade projects with producer groups. Solidar'Monde, founded in 1981 under the name Fam'Import, dedicated itself to imports and distribution to the networks of Artisans du Monde boutiques, shops belonging to the Fair Trade Platform, or boutiques specializing in organic produce (e.g., Biocoop). 


\section{Nil Özçağlar-Toulouse et al.}

National and international networks

During the past three decades, new Fair Trade organizations also have emerged, touting three main objectives: to ensure cohesiveness among the various actors, to implement a network for information exchange, and to pool resources to lobby international bodies. Since the end of the 1980s, highly disparate organizations that previously had coexisted separately began to organize into networks. This approach enabled them to promote fairer trade and open already developed markets to the small producers in underdeveloped countries. Today, the framework defines four types of actors: economically marginal regional producers, commercial or import intermediaries, accrediting organizations that guarantee the Fair Trade nature of products, and retail outlets (see Figure 2).

In 1998, these four networks joined forces in the form of an informal structure called Fine. In France, the French Fair Trade Platform (PFCE), founded in 1997 , is the official national organization that represents actors in the Fair Trade industry. By 2005, it represented 32 national organizations, including importers, distributors, promoters, and accrediting groups, as well as actors that supported the movement, such as boutiques and solidarity groups. In parallel, Minga appeared in 1999 as a splinter association, a result of the departure of Andines from the PFCE, ${ }^{5}$ after it accused Max Havelaar of retaining too much influence. Minga represents approximately 90 persons and structures and provides a voice of dissent that refuses to recognize just one certification system.

From the network to the market

Created in 1992, the Max Havelaar France Association exists to ensure that Fair Trade criteria are adequately met. It relies on FLO Cert $\mathrm{GmbH}$ to certify and monitor various channels.

However, the development of the Fair Trade market also began to interest many new actors, who entered a wide variety of sectors starting in the beginning of the 2000s. The French market generally consists of three types of networks. The first type contains small independent boutiques that obtain their supplies from central Fair Trade purchasing outlets (e.g., Boutic Ethic, Sira Kura, Bébés en Vadrouille, etc.) and young entrepreneurs that brand products imported from central Fair Trade purchasing outlets or through their own channels, such as Alter Eco, Ethiquable, Idéo, Tudo Bom, Veja, or

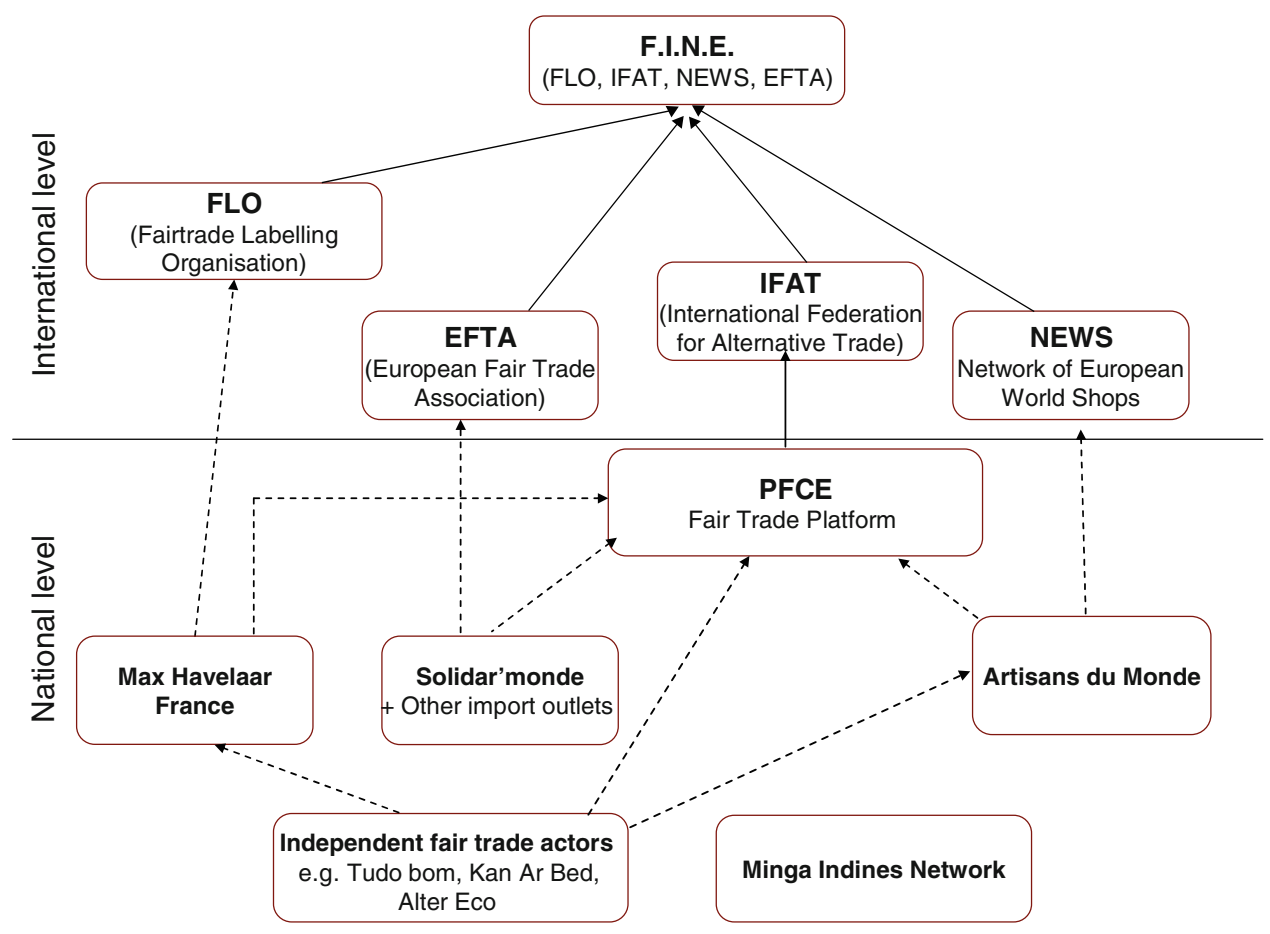

Figure 2. Organization of Fair Trade in France and links with international actors. 


\section{Demystifying Fair Trade in France}

Misericordia. The second network type entails existing retailers, such as 3 Suisses, Monoprix, Leclerc, and Carrefour, that market products from Fair Trade channels under the Max Havelaar label (these products often are from Alter Eco or Ethiquable) to mainstream consumers. Both of these types also have expanded recently into online boutiques. Finally, the third type of network, which continues to develop, appears to comprise a heterogeneous range of actors: entrepreneurs that embrace a social economy, such as actors in the ethical fashion industry, socially responsible, or ethical banks (e.g., Crédit coopératif, $\mathrm{NEF}$ ), and regional or territorial cooperatives from underdeveloped economies. This network therefore relies on varied, hybrid distribution networks, as well as heterogeneous marketing techniques that combine brands, labels, and certification. The actors in this third network can reinforce their weak links and thereby enhance the sense of "fairness" that represents a behavioral norm for actors involved in this sector.

By studying the conditions in which each of these categories of actors emerged, the resources they possess, and the values they defend, we can gain a better understanding of how these configurations have contributed to the development of Fair Trade in France. However, Fair Trade bodies are not satisfied just to demonstrate the possibility of conducting trade fairly; they also want to change the rules of the game.

Micro level: understanding the practices

of Fair Trade organizations

The latest image of French Fair Trade, according to the views that emerge from the interviews, focuses on entrepreneurial activity in various countries, environmental issues, and marketing. Fair Trade organizations also vary according to their support for globalization. Finally, at the micro level, the social role of NGOs has changed in the Fair Trade context.

Alter-global Fair Trade

Alter-globalism ${ }^{6}$ is a heterogenous but generally a reformist approach suggesting a profound reconstruction of existing economic, social, and environmental structures of globalization and promotes the humanist values to take over to the economic logics of the neoliberal globalism. While the organizations adopting an alter-global approach try all to improve the existing market system through better functioning of international trade, they are clearly divided regarding which practices might enhance the development of Fair Trade. The confrontation essentially pits a pragmatic approach against an activist approach, which we illustrate using two cases: Alter Eco and Tudo Bom.

Some organizations believe that integrating Fair Trade into the mainstream is the only possible path. These groups, which usually are for-profit firms, argue that Fair Trade can integrate marginalized producers into the global economic system if, and only if, it guarantees significant sales volumes for these producers. They therefore support Fair Trade products in the aisles of every supermarket and want to employ conventional management techniques to optimize the marketing of Fair Trade products through various distribution channels. Accreditations and labels would serve as identifying marks for Fair Trade products. In addition, the profits earned would enable autonomy, unlike State subsidies. The company synonymous with this approach, Alter Eco, represents a success story for French Fair Trade.

Actor pragmatism: the case of Alter Eco. Alter Eco was founded in 1990 by Tristan Lecomte as an independent boutique for ethical consumers. Despite extensive media coverage, the business failed to make a profit, and its main aim became establishing its legitimacy as a Fair Trade actor and its credibility among distributors. In 1999, in partnership with PwC Consulting, it expanded to the import and distribution of Fair Trade products. In 2006, all Alter Eco products bore the Max Havelaar label, except for products not yet covered by the Max Havelaar certification system.

Its multichannel strategy meant that Alter Eco could increase its business significantly; the establishment of an online shop (alterecodirect.com) in 2006 also offered the possibility of an extended range of products accessible by its equally extensive clientele. Alter Eco's broader distribution enabled it to commit to a multiproduct brand strategy, diversifying its product range in response to pressure from competitors. The company also grew by adopting standard methods for commercial communication and sales promotions (e.g., poster 


\section{Nil Özçağlar-Toulouse et al.}

campaigns, gondola placements, etc.) that were designed to make the products appear "attractive" (an expression that appears frequently in Alter Eco's communications), as well as making efforts to appeal to Fair Trade consumers who usually are hostile to retail distribution channels. Its products appear in most large French food stores, and some of them also bear an "organic agriculture" label. In 2005, the company founded Alter Eco Brazil, a specific structure intended to establish a new network.

Actor activism: the case of Tudo Bom. Another perspective suggests that the primary aim of Fair Trade is to promote consumer awareness and prick consumers' consciences with regard to the socioeconomic problems of globalization. Therefore, for some actors, the future of Fair Trade will demand an alternative network, even if it remains marginal. However, in contrast to the traditional activist position (Moore, 2004; Raynolds et al., 2007), these outsiders also include new Fair Trade companies, which themselves constitute a new category of actors. These companies rely on existing networks to only a small extent or opportunistically to develop and exploit new resources, practices, and networks. For example, the ethical fashion network encompasses fashion brands from Fair Trade textile channels. This hybrid approach appears to both consolidate Fair Trade and enroll major actors from the economic system (e.g., socially responsible finance, entrepreneurs, etc.). However, the extension of the network raises questions about the capacity to maintain trust and vigilance over Fair Trade practices, which are necessary to ensure legitimacy in the eyes of consumers.

Founded in 2004, the Tudo Bom brand of clothing adopts an economic and socially responsible cooperative approach between disadvantaged Brazilian cotton producers and French purchasers. In addition to fair remuneration, the directors of Tudo Bom consider the transfer of information, methods, tools used for analysis, and technical know-how essential. One of its cofounders argues that the social economy is emerging as an "ecosystem favourable to the coexistence of the political project launched at its origin and the commercial requirements for good economic performance in order to ensure the sustainable development of Fair Trade."
In addition to these bipolar conceptions of Fair Trade - that is, pragmatic versus activist - another group of actors embraces an anti-global point of view.

\section{Anti-globalism Fair Trade}

While alter-globalism is a more reformist movement, anti-globalism entails a profound and deeper criticism of the process of globalization. The antiglobal Fair Trade shows a clear and direct rejection of traditional forms of Fair Trade and a refusal to accept conventional actors and their economic reasoning, including the reasoning that supports sustainable development. Instead, these participants prioritize territorial and local issues, which they believe, are the essential foundation for social links. By rejecting industrial and retail systems, these actors subscribe to a system in which domestic considerations prevail (including the theory of conventions). Their resulting hyperbolic reasoning tends to disqualify anything that is not local from consideration. The transit of goods across country boundaries therefore is subject to harsh criticism, regardless of whether the transit is fair or not. In the end, these actors argue, only local Fair Trade makes sense, and so the aim should be to promote Fair Trade markets in confined circuits, dealing in regional products produced by small indigenous producers. Furthermore, this system would be automatically more environmental friendly, because it does not involve lengthy transport and encourages the development of new forms of solidarity.

The values of Fair Trade are not fundamentally different, according to these actors, from initiatives intended to develop alternative economies (Neamtan, 2003). An alternative economy redefines the relationships between the economy and the social sector, without any profit objectives or consideration of efficiency and competitiveness and solely with a focus on morality. The ideological emphasis, which we define as a struggle against socioeconomic exclusion, in turn requires relocalization of Fair Trade to ensure the greatest degree of localization between producers and consumers, representing a link with oneself and a link to nature. The former idea matches the perspectives adopted by growth objectors and voluntary simplicity practitioners. The link with nature encourages establishing roots and being attentive to the development of "non- 
resident" behaviors with regard to social class (Carr, 2004). The main issue thus becomes the environment, rather than questions of social and economic inequality or the observation of basic human rights. This approach challenges the Fair Trade dynamic in France, with its historical and global emphases. The experience of Kan Ar Bed provides a good illustration of this new anti-globalization, bioregionalist wave.

The case of Kan Ar Bed. The cooperative production company Kan Ar Bed ("Song of the World" in Breton) was founded in 2002 to distribute Fair Trade drinks in bars and during entertainment events in Brittany. To this end, Beuk Cola, the first Fair Trade cola, was launched in collaboration with a Breton cooperative brewery, Tri Martold. In parallel, the Solidar'bar project deployed in an effort to create a common label for all bars within the region that adhered to the "linked economy" approach. Specifically, these bars had to commit to serving certain Fair Trade products and remove products produced by multinationals, particularly Coca-Cola, which was to be replaced by Beuk Cola. Kan Ar Bed received significant support from the creation of the Ingalãn ("to distribute, to share, or to equalize" in Breton) Association in Rennes in 2004. The name expresses roots in Brittany and commitment to a solidarity economy. Ingalãn then developed a federation of Fair Trade actors in Brittany, Breizh Ha Reizh ("Brittany and Fair" in Breton), with the aim, according to one of the members, of the development of Fair Trade outside the large- and small-scale retail distribution network.

Other networks also have been mobilized within this confined circuit, including consumer associations that pre-buy producers' harvests, the AMAP (Association for the Maintenance of Small-Farm Agriculture), and producers' cooperatives that run their own boutiques and ensure a shift workforce so that someone is always available to sell produce. The federation campaigns, together with Minga and the Confédération Paysanne, actively work for the development of local Fair Trade and its official recognition in France.

Professional NGO structures and Fair Trade actors

To match growing Fair Trade demands and remain competitive in the market, despite the arrivals of new actors and the concept of "mainstream Fair Trade," more traditional NGOs and actors were forced to enter a rationalization stage, which became synonymous with their increased professionalism.

Consider, for example, the case of the local associations, Artisans du Monde and Max Havelaar (representing more than 200 structures with approximately 6000 volunteers nationwide). For several years, they have engaged in slow, structural evolutions that will transform their organizational frameworks, restructure their managerial and decision-making bodies, and reform their commercial practices. One major development currently involves working to reorganize the bodies and practices according to a specialized division of labor and responsibilities and provide a well-defined method for training volunteers. The aim of these efforts is to go beyond the movement's initial amateur status and present a new image that is not only more professional but also more serious, which should attract new customers, including reticent and skeptical ones who frequently associate voluntary work with amateurism. The associations also hope to improve their operational skills and efficiency to manage the complexity and technical aspects of their tasks, such as coordinating activities and volunteers, establishing systematic elections for their governing bodies, creating working groups with specific responsibilities, and appointing referents to different business sectors (e.g., development, lobbying, sales management, etc.).

Furthermore, these organizations plan to diversify their volunteer recruitment procedures, beyond co-option and mutual recognition, to include appeals to volunteer centers, advertising, open enrollment dates, partnerships with various teaching and training institutions, and so forth. These new methods, along with "job interviews" prior to enrolling the new volunteers, emphasize pride in the skills and knowhow possessed by the new members. Although no volunteers will be refused, the organizations hope to recruit them on the basis of the activities for which they can be of most use, due to their unique professional or educational background. Thus, associations might turn to teachers or retired employees of the French national school system to fill posts in education or development fields, because these activities are directed toward schools and require significant pedagogical and speaking skills. In turn, 


\section{Nil Özçă̆lar-Toulouse et al.}

the volunteers will also be recruited, who possess or can refresh skills that are frequently close to those used in the working world (Havard Duclos and Nicourd, 2005). Furthermore, the broader range of training offered to volunteers forms an increasingly integral part of volunteers' activities. Volunteers are quicker to become operational and effective because of this training, which contradicts the long-standing image of volunteers as those who may be very generous but perhaps less than qualified when it comes to tackling the activities for which they are responsible.

Finally, the associations themselves are becoming more professional and adopting prevalent marketing standards to apply to their products. For example, Artisans du Monde recently modified all of its packaging and applied a common decorating scheme in its boutiques and furniture.

In the end, new procedures represent a response by the associations to the growth in their Fair Trade business, as well as the increasing demands made by customers and commercial partners. By becoming more professional, these associations seek to become more competitive. However, it also means they are moving closer to a traditional company structure, even if doing so means losing part of what marks them as distinctive, which also runs the risk of losing the support of some of their most long-standing and committed activists.

\section{Discussion}

French Fair Trade has progressed considerably in just a few decades. The system that actors use to represent themselves as Fair Trade actors has grown more complex, partly because of its role in determining various institutional projects. Regardless of their nature, socioeconomic innovations in this field have always been motivated by ethical considerations, with the persistent aim: "to do good." However, the implementation of this objective varies widely, depending on the actor. Our analysis of Fair Trade in France therefore consists of two essential dimensions: the substantive dimension, which defines objectives, assignments, and the benefits being sought, and a procedural dimension, which determines actions, programs, and rules for conducting actions.

In the procedural sense, two types of actors stand in opposition. Those opposed to globalization prefer exchanges that may appear functionally and structurally within the market but contrast with that market in ideological terms (Taylor, 2005). According to these proponents, the emphasis must focus on the sociopolitical project of enrolling trade organizations within systems of interpersonal exchanges. Those who support alter-globalization accept commercial anonymity (as well as marketing, management tools, and the professionalization of their business). They support various industrial and trade conventions that can be deployed to ensure the legitimacy of commercial actions (Boltanski and Thévenot, 2006). Thus, the former group, who defend a radical transformation of the rules of the economic game and may even champion negative growth rather than alternative growth, receive strong criticisms of the latter group who defend regulations and strategic concessions to support Fair Trade. These conflicts may explain why many organizations fail in both mainstream and alternative channels, such as the radical mainstreaming companies in the United Kingdom (Low and Davenport, 2005). Such disagreements become especially vehement in response to the emergence of conventional and multinational firms in the Fair Trade sector. For these new actors, the fairness of the exchange is not an end in itself (because fairness muddies the aim of obtaining a good rate of return) but rather a means to attain profitability in the mainstream market. This aim also appears to direct the actions of some pragmatic actors (e.g., Alter Eco) that develop systematic management techniques and thereby commit to a structural and institutional process that diverges from their original cultural framework.

From a substantive perspective, other differences emerge, focused not on management but rather on international aspects. Although the domestic roots of Fair Trade remain a matter of debate, the issue no longer entails changing just the economic scale of Fair Trade; it also includes changing the geographical scale. Artisans du Monde advocate the concept of Fair Trade structured according to a logic of "unique solidarity" (Durkheim, 1997). Organizations such as Breizh ha Reizh instead support Fair Trade structured according to a logic of "mechanical solidarity." The identity of those who benefit from Fair Trade therefore changes as well. These beneficiaries may be in underdeveloped countries (exclusively) or they may include people in developed 
countries (in addition, mainly, or even essentially). In still other cases, Fair Trade operates according to a logic of "organic solidarity" - that is, solidarity with people who represent a difference with the self. Yet another conception of solidarity prefers the near to the far, prompting an anti-global rather than an alter-global perspective, in which Fair Trade must focus on a local field of action.

\section{Conclusion}

Our analysis of the views and practices of French Fair Trade actors thus reveals that they do not share a common definition of it, nor do they agree about the objectives or means of putting Fair Trade into practice. Due to their ideological differences, these various participants confront significant difficulties in bringing Fair Trade up to date, despite the necessity of doing so. These differences of opinion contribute de facto to consumers' disorientation by adding a different level of complexity on top of the wide variety of labels and brands, questions about the traceability of products, and the credibility of the very term "Fair Trade."

Fair Trade seems ambiguous because it covers projects that are contradictory - open versus closed market systems, alter- versus anti-globalization. The concept thus runs the significant risk of losing all specificity and becoming just another voice in the overall noise associated with claims of "responsible" offers. Agreeing on a normative frame of reference is vital. Regardless of current or future difficulties, Fair Trade actors have no choice but to work together to overcome their difficulties.

The presence of competition does not mean the abandonment of cooperation among Fair Trade organizations. The market is far from saturated; notably, it could extend through the coordination of institutional actions. This idea provided the inspiration for a recent initiative undertaken by several organizations: "Fairtrade Towns in Europe." ${ }^{, 7}$ With the support of the European Union, Max Havelaar in France, the Fairtrade Foundation in the United Kingdom, and Max Havelaar in Belgium, this initiative works to create a politically supported emphasis on more responsible consumption that fits within the framework of sustainable development. In search of synergy, Max Havelaar France also works with PFCE (French Fair Trade Platform) and Artisans du Monde, and this collaboration adapted the European requirements to its local specificities to create a French variation of the wider project. The third European Conference, "Fairtrade Towns," was held in Lyon in 2009. Sixteen communities were the pilot Fairtrade Towns and then were joined by other French communities. This collaboration may constitute a likely new market development approach for Fair Trade organizations that holds promise for overcoming some of the difficulties noted previously.

\section{Notes}

1 These data are available from on the respective company's Web sites: http://www.artisansdumonde.org, http://www.maxhavelaarfrance.org/, http://www.minga. net/, and http://www.ethiquable.com.

2 This increase may indicate that France is catching up with its European neighbors, where the practice is more deeply rooted though not much older. For example, Swiss citizens consumed 20 Euros of Fair Trade goods on average in 2006 (per inhabitant per year), compared with 2.80 Euros for French consumers (Max Havelaar France, 2006). In other European countries, the numbers of World Shops (in 2005) are as follows: 800 in Germany, 500 in Italy, 400 in the Netherlands, and 300 in Switzerland and Belgium, but only 165 in France (though in France, the GMS model dominates the market; Krier, 2005, p. 10).

3 Artisans du Monde shops are part of the World Shops network.

4 See Law no. 2005-882 of 02 August 2005, published in the Official Journal no. 179 of 03 August 2005.

5 The cooperative society Andines, founded in 1987, was the first to mention Fair Trade in France. It trademarked the expression with the INPI (French National Intellectual Property Institute) and drew up a charter to seal partnerships that would not make producers in underdeveloped countries economically dependent on importers in developed countries.

6 Alter-globalism (from the French "alter-mondialisme"), also known as alternate globalization, differs from antiglobalism (from the French "anti-mondialisme"). Alterglobalism have been derived from a popular slogan of the movement: "another world is possible" and constitutes a more reformist point of view on globalization, while anti-globalization activists are against any kind of globalization. 


\section{Nil Özçağlar-Toulouse et al.}

7 A Fairtrade Town is a town, city, or village that commits to supporting Fair Trade and using products with the Max Havelaar/Fairtrade Mark.

\section{Acknowledgments}

The authors would like to thank the Fair Trade Platform for its support. This research was financed in part by the PICRI project on Fair Trade, supported by the Ile-de-France region.

\section{References}

Bécheur, A. and N. Toulouse: 2008, Le commerce équitable: entre utopie et marché (Vuibert, Paris).

Béji-Bécheur, A., V. Diaz Pedregal and N. OzcaglarToulouse: 2008, 'Fair Trade - Just How 'Fair' are the Exchanges?', Journal of Macromarketing 28(1), 44-52.

Boltanski, L. and L. Thévenot: 2006, On Justification. The Economies of Worth (Princeton University Press, Princeton).

Carr, M.: 2004, Bioregionalism and Civil Society: Democratic Challenges to Corporate Globalism (UBC Press, Vancouver).

Desjeux, D.: 2004, Les Sciences Sociales (PUF, Paris).

Diaz Pedregal, V. and N. Ozcaglar-Toulouse: 2009, 'L'institutionnalisation du commerce équitable: l'émergence d'une législation relative à un commerce différent', in C. Eberhart (ed.), Traduire nos responsabilités planétaires. Recomposer nos paysages juridiques (Bruylant, Bruxelles), pp. 473-490.

Durkheim, E.: 1997, The Division of Labor in Society (Free Press, New York).

Gateau, M.: 2008, 'Quelle(s) stratégie(s) de distribution pour les produits équitables? Le cas Français ou la difficile alliance entre logique militante et logique commerciale', Économie et Solidarités 37(2), 109-122.

Hasselbladh, H. and J. Kallinikos: 2000, 'The Project of Rationalization: A Critique and Reappraisal of Neo-Institutionalism in Organization Studies', Organization Studies 21(4), 697-720.

Havard Duclos, B. and S. Nicourd: 2005, Pourquoi s'engager? Bénévoles et militants dans les associations de solidarité (Payot, Paris).

Herth, A.: 2005, 'Propositions pour le développement du commerce équitable en France', Rapport remis à l'ancien Premier Ministre Jean-Pierre Raffarin, Mission parlementaire auprès du Ministre délégué aux PME, au Commerce, à l'Artisanat, aux Professions libérales et à la Consommation. IPSOS/Max Havelaar France: 2007, 'Baromètre de notoriété: les Français et le commerce équitable', mars.

Krier, J.-M.: 2005, Fair Trade in Europe 2005. Facts and Figures from Fair Trade in 25 European countries', Report for EFTA, FLO, IFAT and NEWS (Brussels).

Low, W. and E. Davenport: 2005, 'Postcards from the Edge: Maintaining the "Alternative" Character of Fair Trade', Sustainable Development 13, 143-153.

Max Havelaar France: 2006, 'Rapport Annuel', http:// www.maxhavelaarfrance.org/.

Moore, G.: 2004, 'The Fair Trade Movement: Parameters, Issues and Future Research', Journal of Business Ethics 53, 73-86.

Moquet, A.-C. and A. Pezet: 2006, 'Les technologies de la responsabilité sociétale ou l'invention du manager responsable - Le cas Lafarge', Revue Finance-ContrôleStratégie 9(4), 113-142.

Neamtan, N.: 2003, 'L'économie solidaire comme radicalisation de la démocratie', Revue du MAUSS 21, 126-134.

Raynolds, L., D. Murray and J. Wilkinson (eds.): 2007, Fair Trade: The Challenges of Transforming Globalisation (Routledge, New York).

Spanou, C.: 1991, Fonctionnaires et militants - L'administration et les nouveaux mouvements sociaux (L'Harmattan, Paris).

Taylor, P.: 2005, 'In the Market but not of It: Fair Trade Coffee and Forest Stewardship Council Certification as Market-Based Social Change', World Development 33(1), 129-147.

Weber, M.: 1971, Economie et Société (Plon, Paris).

Nil Özçă̆lar-Toulouse Univ Lille Nord de France, Lille, France E-mail:nil.toulouse@univ-lille2.fr

Amina Béji-Bécheur Université Paris-Est, Marne la Vallee, France

Matthieu Gateau Université de Bourgogne, Dijon, France

Philippe Robert-Demontrond University of Rennes 1, Rennes, France 